\title{
On the Relationship of Students' English Learning Beliefs and Learning Strategy in the University
}

\author{
Zhen Zhou \\ Foreign Language School, Nanchang Normal University, Nanchang, Jiangxi, China
}

\begin{abstract}
The research conducts a questionnaire survey and interview on students' English learning beliefs and learning strategy in a particular college in Jiangxi province in order to have a better understanding of college students' English learning beliefs and learning strategy, and the results indicate that the learning beliefs of students is in a middle level, the mean of motivation expectation is the strongest, students overestimate learning difficulties, underestimate their own learning ability, and they have certain wrong beliefs on the understanding of the nature of learning; As for English learning strategy, students' using level is medium, compensation strategy is the most frequently used, and the least frequently used is the memory strategy and affective strategy. English learning beliefs and learning strategy are closely related; English learning beliefs and learning strategy are not correlated with English achievement respectively. Therefore, teachers should help students to establish correct learning beliefs, and pay attention to gender differences in English learning, enhance male students' self-confidence, encourage female students to enhance their confidence, and guide male students to use more memory strategy and social strategy in order to improve the quality of English teaching in normal universities. The purpose of this study is to better understand the English learning beliefs and learning strategy used by normal university students, and to provide some references for improving the quality of English teaching in universities.
\end{abstract}

Index Terms-learning beliefs, motivation expectation, learning strategy, compensation strategy, meta-cognitive strategy

\section{INTRODUCTION}

Language learning beliefs, also known as language learning concepts, refer to the learner's understanding of the nature and process of language knowledge learning (Zhang, 2008), and it is one of the important factors that affect language learning success. At present, the study of language learning beliefs has become a hot topic in the study of second language acquisition. Experts and scholars at home and abroad have studied the beliefs of language learning from different angles and has achieved many results. Horwitz (1987) first proposed the concept of language learning beliefs, and divided language learning beliefs into five factors, namely, foreign language aptitude, language learning difficulty, language learning nature, learning / communicative strategy and motivation. Many studies show that learning beliefs and some individual factors (such as learning strategy, learning style, age, personality, self-efficacy, learning anxiety, learning autonomy, cultural background, individual differences and school differences, academic achievement, gender differences, grade differences and major differences) has significant correlation (Yang, 1999; Dai, 2002; Wu, 2013; Xie, 2014; Song, 2016).

Since 1970s, with the emphasis on applied linguistics shift from "teaching" to "learning", the learning strategy has aroused widespread concern in the field of linguistics (Flavel, 1971; Cotterall, 1999; Aek Phakiti, 2003; Bernat, 2006; Wen, 2001; Liu, 2017; Wang, 2017). The domestic and foreign language researchers conducted a lot of research on learning strategy from the classification, influence of learning strategy on learning factors, learning strategy selection, relationship between learning strategy and academic achievement, strategy training, and reading, writing, listening, vocabulary learning strategy in different aspects in detail and other aspects of the investigation (Rubin, 1987; O 'Malley \& Chamot, 1990; Wen, 2001; Gong, 2008; Chang, 2012; Huang. 2017; Du, 2017; Gao, 2017), and formed a basic consensus, namely, language learning strategy is an important means for students to learn to study. The classification of language learning strategy is still controversial, and Oxford's (1990) classification is the most comprehensive and detailed one, that is, the language learning strategy is classified into two categories: direct strategy (including memory strategy, cognitive strategy and compensation strategy) and indirect strategy (including meta-cognitive strategy, affective strategy and social strategy).

In conclusion, the current study of English learning beliefs and learning strategy is usually separate, and the research object generally focuses on college English major undergraduate or graduate students. However, the study combines learning beliefs and learning strategy together taking students in the second level university as research subjects, which is particularly scarce. This study intends to explore the relationship between learning beliefs, learning strategy and academic performance based on the learning characteristics of the second level university, so as to find a reliable way to 
improve the quality of English teaching in the second level university.

\section{RESEARCH MethodS}

\section{A. Subjects}

The subjects of this study are English majors, 105 Junior students chosen from three randomly selected classes of $\mathrm{t}$ the second level university in Jiangxi province. The questionnaire was issued and retrieved on the spot in class in the second week of the autumn semester of 2016, and the actual recovery of effective questionnaires were 100 copies, of which 90 female students, 10 male students.

\section{B. Research Instrument}

Data were obtained through questionnaires and interviews. Two questionnaires were used in the study: language learning beliefs questionnaire and English learning strategy questionnaire. "Language learning beliefs questionnaire" is the Chinese version of "The inventory of beliefs of language learning" designed by Horwitz (1987). The questionnaire uses Likert's five scale scores, with a total of 34 items, including five factors: foreign language learning aptitude, language learning difficulty, language learning nature, learning / communicative strategy and motivation / expectation. "The English learning strategy questionnaire", is the Chinese version of "English learning strategy questionnaire" by Oxford (1990) and the questionnaire consists of 50 items, including six factors, namely, memory strategy, cognitive strategy, compensation strategy, meta-cognitive strategy, affective / social strategy. The English academic score of this study adopts the score of CET4 (College English Test Band 4) (at the research time, students have not yet sat for the test of TEM4 (Test for English majors). The interviewees were randomly selected from 5 classes in three classes, with a total of 15 students. The interview time of each student was 5 minutes. The main purpose is to illustrate the answers to the questionnaire.

\section{Data Processing}

SPSS 22.0 software was employed to conduct descriptive statistical analysis and correlation analysis of the 100 valid questionnaire data collected.

\section{RESEARCH RESULTS AND ANALYSIS}

\section{A. General Usage of Language Learning Beliefs}

Learning beliefs are important affective factors for learners in English learning which guides students' learning activities. Through descriptive statistical analysis of students' beliefs about English learning (Table1), among all the factors of learning beliefs, motivation / expectation, and learning / communicative strategy have the highest mean, and the mean of language learning nature and learning aptitude is the lowest. The average score of CET4 is only 478, and the standard deviation is 35.8346. As for the English majors in the second level university, the overall level of students' English achievement is not satisfactory.

TABLE1

DESCRIPTIVE STATISTICAL ANALYSIS OF STUDENTS' ENGLISH LEARNING BELIEFS

\begin{tabular}{lllll}
\multicolumn{4}{c}{ DESCRIPTIVE STATISTICAL ANALYSIS OF STUDENTS' ENGLISH LEARNING BELIEFS } \\
\hline & $\min$ & $\max$ & $\operatorname{mean}$ & SD \\
\hline General learning beliefs & 2.65 & 3.76 & 3.3322 & .24046 \\
Motivation/expectation & 2.75 & 4.50 & 3.6379 & .45647 \\
Learning/communicative strategy & 2.43 & 4.29 & 3.5108 & .43823 \\
Language learning difficulty & 2.00 & 4.50 & 3.2557 & .36168 \\
Language learning nature & 2.45 & 3.91 & 3.2270 & .40429 \\
Language learning aptitude & 2.40 & 4.10 & 3.1245 & .38325 \\
CET4 score & 410 & 545.3448 & 477.6724 & 35.83460 \\
\hline
\end{tabular}

The mean of students' motivation/expectation is the highest, which indicates that students have some strong motivation to learn English, and have strong expectations and anticipations for their English learning. The students pay more attention to the learning / communicative strategy, and think that learning English is very important. Students are also willing to actively seek opportunities to communicate with others, better at using social resources to learn English, and they can also realize the importance of improving their comprehensive ability of English, especially the importance of oral communicative ability. The mean of learning aptitude is lowest and the minimum is only 2.4 , which demonstrates that students generally overestimate learning difficulties, lack confidence in their own learning ability, and underestimate their language learning ability. The mean of language learning difficulty is in the last third. The minimum value is only 2 , showing that students have some difficulties. There is a deviation as for the students' understanding of the nature of language learning and they lay excessive emphasis on English grammar learning.

\section{B. General Usage of Language Learning Strategy}

The choice and use of English learning strategy is crucial to students' English learning. The descriptive statistical analysis based on students' learning strategy (Table 2) indicates that, the mean of the students' use of language learning strategy participated in the survey is between 2.5 and 3.4, which shows that students only sometimes use learning 
strategy, and learning strategy use level is not high, but the frequency of use is in a balance. Specifically, the compensation strategy has the highest frequency of use, followed by meta-cognitive strategy and social strategy, and the most commonly used are affective strategy and memory strategy. Compensation strategy is the strategy used by learners to gain more communicative resources, maintain communication and improve communicative effects. This study shows that students can actively approach English difficulties and flexibly use English in their English learning to some extent. Students have a certain sense of meta-cognition, and have the ability of self-management, self-planning, self-regulation and self-evaluation. Memory strategy has the lowest mean value, less than 3, which shows that students are not good at using memory strategy. The most commonly used memory strategy is rote learning, and the students are not familiar with other memory strategy, which is rarely used. The frequency of students' affective strategy is not high, the standard deviation is the largest (.67619), and the minimum is only 1.33, which shows that students have some shortcomings in overcoming anxiety, encouraging themselves and managing their own emotions. The results are different from those of Zhang's (2008) and Liu's (2010). The reason may lie in the different research subjects.

TABLE 2

\begin{tabular}{lllll}
\multicolumn{5}{l}{ DESCRIPTIVE STATISTICAL ANALYSIS OF STUDENTS' USAGE OF LANGUAGE LEARNING STRATEGY } \\
\hline & $\min$ & $\max$ & $\operatorname{mean}$ & SD \\
\hline General learning strategy & 2.34 & 4.02 & 3.0900 & .41579 \\
Compensation strategy & 2.33 & 4.83 & 3.3080 & .50058 \\
Meta-cognitive strategy & 2.00 & 4.56 & 3.2271 & .57899 \\
Social strategy & 1.67 & 4.17 & 3.1051 & .55595 \\
Cognitive strategy & 2.07 & 4.29 & 3.0621 & .47729 \\
Affective strategy & 1.33 & 4.50 & 3.0616 & .67619 \\
Memory strategy & 1.44 & 4.11 & 2.8599 & .51450 \\
\hline
\end{tabular}

\section{Gender Differences of Language Learning Beliefs and Learning Strategy}

Through the independent sample T test on English learning beliefs and learning strategy of male and female students (Table 3), in the aspects of the general learning strategy, compensation strategy, meta-cognitive strategy, affective strategy and cognitive strategy, while female students' mean is lower than that of female students, yet there is no significant difference in the use of these aspects, and the level of their language learning strategy is very similar. And there are significant gender differences in social strategy and memory strategy.

TABLE 3

\begin{tabular}{|c|c|c|c|c|c|}
\hline \multirow{3}{*}{ General learning beliefs } & gender & mean & SD & $\mathrm{t}$ & Sig. \\
\hline & $\mathrm{F}$ & 3.2839 & .26030 & \multirow{2}{*}{-1.162} & \multirow{2}{*}{.252} \\
\hline & M & 3.4608 & .08985 & & \\
\hline \multirow{2}{*}{ Motivation /expectation } & $\mathrm{F}$ & 3.7267 & .42892 & \multirow{2}{*}{.239} & \multirow{2}{*}{.812} \\
\hline & M & 3.6667 & .14434 & & \\
\hline \multirow{2}{*}{ Learning/communicative strategy } & $\mathrm{F}$ & 3.5449 & .44553 & \multirow[b]{2}{*}{-.101} & \multirow{2}{*}{.920} \\
\hline & M & 3.5714 & .37796 & & \\
\hline \multirow{2}{*}{ Language learning difficulty } & $\mathrm{F}$ & 3.3333 & .58141 & \multirow{2}{*}{-1.061} & \multirow{2}{*}{.039} \\
\hline & M & 2.9651 & .57735 & & \\
\hline \multirow{2}{*}{ Language learning nature } & $\mathrm{F}$ & 3.1755 & .30630 & \multirow{2}{*}{-1.212} & \multirow{2}{*}{.232} \\
\hline & M & 3.3939 & .18924 & & \\
\hline \multirow{2}{*}{ Language learning aptitude } & $\mathrm{F}$ & 3.1070 & .36148 & \multirow{2}{*}{-1.367} & \multirow{2}{*}{.017} \\
\hline & M & 3.4000 & .30000 & & \\
\hline \multirow{2}{*}{ Learning strategy } & $\mathrm{F}$ & 3.1060 & .42362 & \multirow{2}{*}{.991} & \multirow{2}{*}{.327} \\
\hline & M & 2.8600 & .19079 & & \\
\hline \multirow{2}{*}{ Compensation strategy } & $\mathrm{F}$ & 3.3101 & .51252 & \multirow{2}{*}{0.107} & \multirow{2}{*}{0.300} \\
\hline & M & 3.2778 & .34694 & & \\
\hline \multirow{2}{*}{ Meta-cognitive strategy } & $\mathrm{F}$ & 3.2326 & .59580 & \multirow{2}{*}{0.242} & \multirow{2}{*}{0.810} \\
\hline & M & 3.1481 & .27962 & & \\
\hline \multirow{2}{*}{ Social strategy } & $\mathrm{F}$ & 3.1240 & .56938 & \multirow{2}{*}{.873} & \multirow{2}{*}{.038} \\
\hline & M & 2.8333 & .16667 & & \\
\hline \multirow{2}{*}{ Cognitive strategy } & $\mathrm{F}$ & 3.0781 & .48940 & \multirow{2}{*}{.856} & \\
\hline & M & 2.8333 & .10911 & & .397 \\
\hline Affective strate $\sigma y$ & $\mathrm{~F}$ & 3.0698 & .69506 & 307 & 147 \\
\hline Affective strategy & M & 2.9444 & .34694 & .301 & $.14 /$ \\
\hline Memory strategy & $\mathrm{F}$ & 2.8992 & .48177 & & \\
\hline Memory strategy & M & 2.2963 & .75632 & 1.362 & .030 \\
\hline & $\mathrm{F}$ & 523 & 10.0324 & & \\
\hline English score & M & 430 & 20.357 & 1.121 & .243 \\
\hline
\end{tabular}

In the general learning beliefs, learning/communicative strategy, language learning nature, the mean of male students is higher than that of female students, but there is no significant difference. In motivation/expectations, the mean of female students' is higher, indicating that female students have much stronger motivation to learn English, but there is still no significant difference. In learning difficulty and foreign language learning aptitude, there is a significant difference between male students and female students, male students think learning English is easier, and their learning 
aptitude is also higher. And there is no significant difference between male and female students in English learning achievement.

\section{The Relations among the Learning Beliefs, Learning Strategy and English Score}

The results of Pearson correlation analysis of English learning beliefs and learning strategy of students indicates that (Table 4): 1) The general learning beliefs has a significant positive correlation with cognitive strategy, compensation strategy, meta-cognitive strategy, the general learning strategy, which means that the higher the level of learning beliefs, the more frequent use of cognitive strategy, compensation strategy, meta-cognitive strategy, and general learning strategy; 2) Learning aptitude has significant positive correlation with cognitive strategy, compensation strategy, meta-cognitive strategy and general learning strategy. The more students believe that they have language learning ability, the more they use cognitive strategy, compensation strategy, meta-cognitive strategy and general learning strategy; 3) Learning / communicative strategy has a significant positive correlation with general learning strategy. Because learning / communicative strategy belongs to learning beliefs, and belong to the learning strategy as well, which overlaps; 4) There is a significant positive correlation between motivation and compensation strategy, that is, motivation is higher, students use compensation strategy more frequently; 5) General learning strategy and its factors are not related to and the English achievement; 6) General learning beliefs and its factors are not related to the English achievement.

TABLE 4

PEARSON CORRELATION ANALYSIS OF ENGLISH LEARNING BELIEFS AND LEARNING STRATEGY

\begin{tabular}{|c|c|c|c|c|c|c|c|}
\hline & $\begin{array}{l}\text { Language } \\
\text { aptitude }\end{array}$ & $\begin{array}{l}\text { Language } \\
\text { learning } \\
\text { difficulty }\end{array}$ & $\begin{array}{l}\text { Language } \\
\text { learning } \\
\text { nature }\end{array}$ & $\begin{array}{l}\text { Learning/ } \\
\text { communicative } \\
\text { strategy }\end{array}$ & $\begin{array}{l}\text { Motivation/exp } \\
\text { ectation }\end{array}$ & $\begin{array}{l}\text { General } \\
\text { learning } \\
\text { beliefs }\end{array}$ & $\begin{array}{l}\text { English } \\
\text { score }\end{array}$ \\
\hline Memory strategy & .187 & -.096 & .116 & .269 & .184 & .240 & .037 \\
\hline Cognitive strategy & $.318 *$ & .080 & .262 & .279 & .257 & $.391 * *$ & -.049 \\
\hline Compensation strategy & $.363 *$ & -.007 & .079 & .166 & $.401 *$ & $.316^{*}$ & -.123 \\
\hline Cognitive strategy & $.345^{*}$ & .136 & .214 & .165 & -.007 & $.301 *$ & -.092 \\
\hline Affective strategy & .246 & .110 & .022 & .241 & .026 & .215 & -.058 \\
\hline Social strategy & .242 & .084 & .013 & .191 & .153 & .213 & -.122 \\
\hline General learning strategy & $.370 *$ & .072 & .182 & $.293^{*}$ & .209 & $.376^{* *}$ & -.079 \\
\hline English score & -.168 & .067 & .248 & .200 & .063 & .117 & 1 \\
\hline
\end{tabular}

\section{DISCUSSION}

\section{A. The Students' English Learning Beliefs at a Middle Level with a Large Deviation}

Among the factors of learning beliefs, motivation/expectation and learning/communicative strategy have the highest mean value, and the mean of language learning nature and learning aptitude is the lowest. Comparatively speaking, the students' motivation is the strongest, 94\% the students want to learn English well, and English learning motivation is clear, but most motivation is external instrumental motivation, most students' motivation is to find a decent job, students often easily give up because of external factors. Therefore, teachers should focus on cultivating students' intrinsic motivation of English learning, and guide students to combine the internal integration motivation and extrinsic instrumental motivation, so that students will learn to learn happily, and also improve learning efficiency. Most students lack confidence in English learning, underestimate their ability to learn English, overestimate and fear learning difficulties. Although they think they are good at English learning, they cannot reach the level of "special ability", and they do not see their potential. Nearly half of the students think that they cannot learn English well, because of many reasons, such as fear of difficulties, lack of willpower, negative attribution, lack of self-confidence, weak English foundation, heavy schoolwork, examination pressure, employment pressure and so on. The students' understanding of the of English learning nature is vague and there are some deviations. Most students pay too much attention to the study of English grammar, and think grammar learning is the most important, ignoring the importance of English communicative ability.

\section{B. The Students' Use of English Learning Strategy at a Medium Level}

Students in the study only use English learning strategy sometimes, and their use of English learning strategy is not high. Among the factors of English learning strategy, compensation strategy is the most frequently used, followed by meta-cognitive strategy and social strategy, and the least frequently used ones are affective strategy and memory strategy. Memory strategy have the smallest mean, which indicates that students are not good at using memory strategy, and their most commonly used memory strategy is rote learning, and they are not familiar with other memory strategy, which are rarely used. English learning is a process fighting against forgetting, so the memory strategy is extremely important, teachers should guide students to master some useful memory strategy, such as lexical chunks, understanding method, organization chart method, visualization, association, rhyming, presentation, writing a sentence, the initial letter and taking notes and reading aloud method, singing, fun method, segmentation method, comparative method, selfquestioning method, transliteration, repeating and so on. The deviation of affective strategy is the largest, and the 
difference between students is large. The frequency of students' affective strategy is not high, which shows that students have some shortcomings in overcoming anxiety, encouraging themselves and controlling emotions, and students are not confident enough. Therefore, students can use self-suggestion, self-encouragement, self-reward and other methods to regulate emotions, and they usually also need to practice English, make adequate preparations, enhance self-confidence, improve self-efficacy, conduct positive self-attribution, and improve the frequency of affective strategy use.

\section{There Are Gender Differences in Some Factors of English Learning Beliefs and Learning Strategy}

Among the factors of social strategy and memory strategy, the mean of female students' is higher than that of male students, and there is significant gender difference. Female students are better at using social strategy, and better at communicating with others, and while meeting with learning difficulties, they often try to seek help from others, while male students are usually independent, single handed, dislike cooperation, and do not like to turn to others for help. Teachers should encourage male students to grasp communicative opportunities both in and out of class, communicate with others in English, focus on meaning expression rather than fluency in communication, and encourage male students to seek help when they are in trouble. Compared with male students, female students are better at using memory strategy, and they are more attentive and careful. Therefore, more memory strategy is used by female students, and the frequency of use is higher. On English learning motivation / expectations, female students have higher mean, and female students' English learning motivation in general are much clearer than taht of male students, and the interview results also show that the female students' internal integration motivation is stronger, but there is no significant difference between male and female students. But in learning difficulties and foreign language learning aptitude, there is a significant difference between male and female students. Although male students are not as good as female students in English, male students are more optimistic and confident in English learning, and have higher self-efficacy. They think learning English is easier and learning aptitude is also higher.

\section{English Learning Beliefs Closely Related to Learning Strategy}

English learning beliefs and learning strategy are inseparable, and the relations are as follows, 1) The general learning beliefs have significantly positive correlation with cognitive strategy, compensation strategy, meta-cognitive strategy and general learning strategy respectively, namely, the higher level the general learning beliefs, the higher using frequency of cognitive strategy, compensation strategy, meta-cognitive strategy and general learning strategy. 2) Learning aptitude has significantly positive correlation with cognitive strategy, compensation strategy, meta-cognitive strategy and general learning strategy. The more students believe that they have language learning ability, the more they use cognitive strategy, compensation strategy, meta-cognitive strategy and general learning strategy; 3) the general learning strategy and learning / communicative strategy are significantly positively correlated. Because learning/ communicative strategy belong to both learning beliefs and learning strategy, so there is a overlapping; 4) There is a significant positive correlation between motivation and compensation strategy, and the higher the motivation is, the higher the frequency of compensation strategy is. The English learning beliefs and learning strategy are closely related, therefore, English teachers should pay more attention to the students' English learning beliefs, correct the errors of students learning concept, guide students to establish a correct concept of learning, stimulate students' English learning motivation, and enhance students' self-confidence, which can make students more frequent and more effective users of English learning strategy, and teachers should promote English learning, and improve English learning achievement.

\section{E. English Learning Beliefs and Learning Strategy not Related to English Achievement}

Learning beliefs and learning strategy have some influence on English learning achievement, but they are not related to English learning achievement. The results are quite different from those found by some experts and scholars. Liu's (2003) research on English learning beliefs shows that there is a significant negative correlation between motivation concept and English achievement, and there is a positive correlation between language learning beliefs and English achievement. The study of Mei (2013) pointed out that the learning difficulty concept was positively correlated with the CET4 achievement, and the learning nature was negatively correlated with CET4 achievement; the difficulty of foreign language learning had predictive power to the CET4 achievement, and the learning nature had negative predictive power to CET4 achievement. About English learning strategy, Gong's (2008) study shows, except that compensation and memory strategy are not related, the other learning strategy have significant correlation in between; Among the six kinds of learning strategy, memory strategy, cognitive strategy and meta-cognitive strategy affect turbine students' English achievement most. Zhang's (2009) study has shown that memory strategy is positively correlated with the English achievement, and other learning strategies are not related to academic achievement. There are many reasons for the differences, and one of the most important factors is that there are differences among the subjects.

\section{CONCLUSION}

This paper analyzes the relationship between English learning beliefs, learning strategy and English achievement through questionnaire and interview on English majors in a normal university. The results show that the students' English learning beliefs are in the middle level, and there is a big deviation; The students' use of English learning strategy is in the middle level; There are gender differences in certain factors English learning beliefs and learning 
strategy; English learning beliefs and learning strategy are closely related; English learning beliefs and learning strategy are not correlated with English achievement respectively.

The research results offer some implications for the college English teaching. On the one hand, the teacher should understand the students' English learning beliefs, guide students to make a correct evaluation of their own English learning beliefs, help students to turn correct ideas into action, and guide students to learn how to use their own resources; Teachers should correct students' wrong ideas about language learning, help students to establish correct beliefs of learning, and improve students' level of English learning beliefs and cognition and action. On the other hand, teachers should pay attention to gender differences in the English teaching. Teachers should encourage, guide female students to conduct success-ability attribution and fail-effort attribution, and seek to improve self-confidence and learning aptitude; Besides, the teacher should guide the male students to use more memory strategy and social strategy, guide them to flexibly use more memory strategy, and encourage them to actively make use of social resources and engage in the cooperation learning.

\section{ACKNOWLEDGEMENTS}

This study was financially supported by humanistic project of Nanchang Normal University (15RWYB21).

\section{REFERENCES}

[1] Aek Phakiti. (2003). A closer look at the relationship of cognitive and meta-cognitive strategy use to EFL reading achievement test performance. Language Test, 20(1): 26-56.

[2] Bernat, E. (2006). Assessing EAP learners' beliefs about language learning in the Australian context. Asian EFL Journal, 2006, 8(2): 202-227.

[3] Chang H.C. (2012). The mediating effect of learning strategy on ambiguity tolerance and English proficiency. Foreign Language Circles, 149 (2): 81-88.

[4] Cotterall, S. (1999). Key variables in language learning: What do learners believe about them? System, 27(3): 493-513.

[5] Dai W. D., Wang D. (2002). An investigation and analysis of English Majors' language learning beliefs. Foreign Language Circles, 5, 24-29.

[6] Du H.Q. (2017). English learning strategy in flipped classroom. Journal of Hubei University of Education, 1, 112-115.

[7] Flavell, J. H. (1971). First discussant's comments: What is memory development?. Human Development, 14, $272-278$.

[8] Gao L. X., Zhu G L. (2017). A comparative study of English learning strategy between gifted students and underachievers in high school. Foreign Language Teaching Research in Basic Education, 5, 58-61.

[9] Gong X. J. (2008). The quantitative research and analysis of students' language learning strategy. Foreign Language Teaching and Research, 231 (6): 38-41.

[10] Horwitz, E. (1987). Surveying student beliefs about language learning. In A. Wenden \& J. Rubin (eds.). Learner Strategy in Language Learning. New York: Prentice Hall, 20(2). 119-132.

[11] Huang R. (2017). Review of English learning strategy. Contemporary Educational Practice and Teaching Research, 4, 83-84.

[12] Liu R.Q. (2003). The reform status and development strategy of Chinese college foreign language teaching. Beijing: Foreign language teaching and research press.

[13] Liu X. Y. (2017). On the Strategy of grammar teaching in junior high school. English Teachers, 1, 100-102.

[14] Liu Y. J. (2010). The quantitative research and analysis of relationship between college English learning beliefs, self-efficacy and learning strategy. Foreign Language Teaching, 31 (4): 65-69.

[15] O’Malley, Chamot. (1990). Learning strategy in second language acquisition. Cambridge: Cambridge University Press.

[16] Oxford. R. (1990). Language learning strategy: what every teacher should know. New York: Newbury House.

[17] Rubin, J. (1987). Learner strategy: theoretical assumptions, research history and typology. In Wenden and Rubin (eds),. Learner Strategy in Language Leaning. Englewood Cliffs: Prentice Hall.

[18] Song T. H. (2014). An Empirical Study of learning beliefs of Australian second language learners. Journal of PLA Foreign Languages Institute, 37 (5): 44-49.

[19] Wang J. (2017). Study on the cultivation of high school students' English learning strategy based on the new English standard. Journal of Kaifeng Institute of Education, 5, 188-189.

[20] Wen Q. F. (2001). Changing rules and characteristics of English learners' motivation, beliefs and strategy. Foreign Language Teaching and Research, 2, 105-110.

[21] Wu G. J. (2013). Translation beliefs and development characteristics of English majors. Foreign Language Circle, 1, 72-78.

[22] Xie Y. M. (2016). Study of the correlation between English learning beliefs, learning strategy and achievement of senior high school students. Basic Foreign Language Education, 6, 8-14.

[23] Yang, Nae Dong. (1999). The Relationship between EFL learners' beliefs and learning strategy use. System, 27(3): 515-535.

[24] Zhang Q. Z. (2008). The influence of foreign language learning beliefs on learning strategy choice. Foreign Language Teaching, $2,43-45$.

Zhen Zhou was born in Ezhou, Hubei province, China in 1981. She received her master degree in English teaching method from Hubei University, China in 2008.

She is currently a lecturer in the School of Foreign Languages, Nanchang Normal University, Nanchang, China. Her research interests include English teaching psychology and English teaching method. 